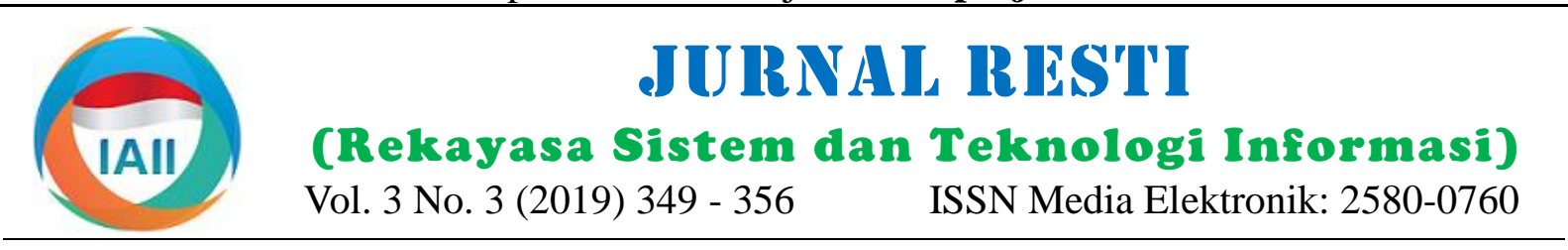

\title{
Rancang Bangun Game Edukasi Biologi untuk Peningkatan Pemahaman Materi Genetika
}

\author{
Fahrudin Mukti Wibowo ${ }^{1}$, Muhammad Alfi Ramadhani ${ }^{2}$ \\ ${ }^{12}$ Teknik Informatika, Fakultas Teknologi Industri dan Informatika, Institut Teknologi Telkom Purwokerto \\ ${ }^{1}$ fahrudin@ittelkom-pwt.ac.id, ${ }^{2}$ alfi@ittelkom-pwt.ac.id
}

\begin{abstract}
Education systems in schools today are generally still oriented to the material media books and verbal material delivery by the teacher. This problem raises the lack of understanding and lack of interest of students in understanding material, especially in Biology chapter Genetics. The learning media provided by the teacher are felt to be lacking to support the achievement of maximum student learning achievement. Therefore an interesting learning media is needed that aims to foster students 'interest in learning and increase students' understanding of genetic material. Alternative learning media that can be used is with educational games. In the process of developing this educational game using the Flash-based waterfall method. The selection of the waterfall method is because the process of making each stage is systematic, meaning that each stage is interrelated so that it can facilitate the making of the system. The results of this study were in the form of an educational game "The Adventure of Cali-Cali" which was tested on students to find out the improvement in learning achievement. From the data obtained at the pretest results show that students still do not understand the genetic material provided by the teacher. This is evidenced by as many as $90.3 \%$ of students who have not met the KKM standard (Minimum Completion Criteria). Then the treatment game was given when the posttest showed that as much as $6.50 \%$ of students did not meet the KKM. The comparison of the results of the pretest and posttest showed an increase in student learning achievement which increased to $83.8 \%$. The pretest and posttest data were tested quantitatively using an interconnected $t$-test, it was found that there were significant differences between the scores / mean scores of the pretest and posttest. While the questionnaire data was tested qualitatively to determine student opinions.
\end{abstract}

Keywords: learning media, waterfall method, genetic material, educational games, flash

\begin{abstract}
Abstrak
Sistem pembelajaran di sekolah saat ini umumnya masih berorientasi pada media buku materi dan penyampaian materi secara verbal oleh guru. Permasalahan ini menimbulkan ketidakpahaman dan kurangnya minat siswa di dalam memahami suatu materi, khususnya pada materi Biologi bab Genetika. Media pembelajaran yang diberikan oleh guru dirasa masih kurang untuk mendukung tercapainya prestasi belajar siswa yang maksimal. Oleh karena itu dibutuhkan media pembelajaran yang menarik yang bertujuan untuk menumbuhkan minat belajar siswa dan meningkatkan pemahaman siswa dalam materi genetika. Media pembelajaran alternatif yang dapat digunakan adalah dengan game edukasi. Dalam proses pengembangan game edukasi ini menggunakan metode waterfall berbasis Flash. Pemilihan metode waterfall karena proses pembuatan tiap tahapnya sistematis, artinya setiap tahap saling berkaitan, sehingga mampu memudahkan dalam pembuatan sistem. Hasil dari penelitian ini berupa game edukasi " The Adventure Of Cali-Cali” yang diujikan kepada siswa untuk mengetahui peningkatan prestasi belajar. Dari data yang diperoleh pada hasil pretest menunjukkan bahwa siswa masih belum memahami materi genetika yang diberikan oleh guru. Hal ini dibuktikan dengan sebanyak $90.3 \%$ siswa yang belum memenuhi standar KKM (Kriteria Ketuntasan Minimal). Kemudian diberikan treatment game ketika posttest yang menunjukkan bahwa sebanyak 6,50\% siswa belum memenuhi KKM. Dari perbandingan hasil pretest dan posttest menunjukan peningkatan prestasi belajar siswa yang meningkat menjadi 83,8\%. Data pretest dan posttest diuji secara kuantitatif dengan menggunakan uji t berpasangan saling berhubungan, diperoleh bahwa ada perbedaan yang signifikan antara nilai/skor rata-rata pretest dan posttest. Sedangkan data kuesioner diuji secara kualitatif untuk mengetahui pendapat siswa.
\end{abstract}

Kata kunci: media pembelajaran, metode waterfall, materi genetika, game edukasi, flash 


\section{Pendahuluan}

Unsur dalam memperoleh ilmu pengetahuan salah satunya yaitu dengan pendidikan. Pendidikan Penelitian lainnya yang diteliti Ghea Putri Fatma Dewi merupakan upaya untuk membantu siswa dalam dengan judul Pengembangan Game Edukasi pengembangan diri khususnya intelektual, psikologis, Pengenalan Nama Hewan dalam Bahasa Inggris maupun moral mereka. Dalam perkembangannya, sebagai Media Pembelajaran Siswa SD Berbasis sebagian besar tugas pendidikan dijalankan oleh Macromedia Flash menggunakan metode penelitian institusi yang disebut sekolah. Pendidikan dapat pengembangan Research \& Development (R\&D). dijadikan sebagai acuan sebuah bangsa dikatakan maju Penelitian ini diangkat dari permasalahan utama yaitu dan berkembang. Semakin baik pendidikan dari sebuah bahwa pada pembelajaran bahasa Inggris kelas IV di bangsa, maka sumber daya manusia dari bangsa itu SD Negeri Somokaton dalam masalah ini banyak siswa semakin baik. Penggunaan teknologi diharapkan dapat kesulitan dalam menghafalkan dan menuliskan susunan meningkatkan kualitas dan kinerja pendidikan. huruf saat menyebutkan nama hewan, untuk itu Teknologi akan mampu mempermudah tugas guru dikembangkan game edukasi pengenalan nama hewan dalam memberikan materi pelajaran. Penggunaan dalam bahasa Inggris untuk memudahkan guru dalam media yang tepat akan memberikan pengalaman belajar penyampaian materi yang digunakan untuk siswa kelas yang tepat kepada siswa, sehingga siswa dapat IV dalam kegiatan pembelajaran di SD Negeri membangun sendiri pengetahuannya tentang suatu Somokaton. Penelitian ini bertujuan untuk konsep.

Umumnya sistem pembelajaran di sekolah masih berorientasi pada media buku materi dan penyampaian materi secara verbal oleh guru. Pengalaman belajar yang rendah yang berasal dari penyampaian materi oleh Penelitian oleh Nelly Indriani Widiastuti, Irwan guru akan berdampak pada rendahnya kemampuan Setiawan dengan judul Membangun Game Edukasi berpikir dan penguasaan konsep siswa, termasuk dalam Sejarah Walisongo mengacu pada masalah kurangnya pelajaran Biologi. Salah satu materi di pelajaran minat siswa untuk mempelajari materi pelajaran sejarah Biologi adalah materi Genetika. Hasil penelitian tentang walisongo dalam mata pelajaran Ilmu tentang pemahaman konsep genetika oleh siswa setelah Pengetahuan Sosial pada bab Sejarah Kebudayaan pembelajaran adalah sebagai berikut. Siswa sering tidak Islam di kelas VI. Paradigma siswa-siswi pada mata merekonstruksi pemikirannya setelah pembelajaran pelajaran tersebut menganggap materi tersebut sulit genetika, sehingga siswa sulit memahami [1].

Salah satu alternatif metode pembelajaran pada pelajaran Biologi dengan materi Genetika adalah metode dalam bentuk game edukasi. Game edukasi adalah permainan yang dirancang untuk merangsang serta meningkatkan daya pikir dan konsentrasi dalam memecahkan masalah [2]. Game edukasi menjadi salah satu media pendukung yang dapat digunakan untuk memberikan materi pelajaran. Game edukasi mampu memberikan pengetahuan bagi para siswa dengan cara yang unik dan menarik. Game edukasi dapat digunakan sebagai salah satu media edukasi yang memiliki pola pembelajaran learning by doing.

Penelitian yang telah dilakukan tentang perancangan game edukasi adalah berjudul Pembuatan Game Edukasi "Petualangan Si Gembul" Sebagai Pembelajaran Pengenalan Daerah Solo Raya pada Anak menggunakan metode waterfall. Pada penelitian ini terdapat masalah bahwa pada kebanyakkan siswa kelas V SD belum mengetahui daerah-daerah mana saja yang masuk dalam daerah Solo Raya, sehingga untuk memudahkan siswa kelas V SD dalam mempelajari mata pelajaran Ilmu Pengetahuan Sosial (IPS) tentang suatu wilayah khususnya wilayah Solo Raya maka mengembangkan sebuah media pembelajaran yang layak untuk digunakan sebagai proses pembelajaran bahasa Inggris dengan materi mengenal nama-nama hewan [4]. untuk dihafalkan. Oleh karena itu, dibutuhkan media pembelajaran yang unik untuk membantu guru dalam menyampaikan materi pembelajaran sejarah walisongo sehingga dapat menarik perhatian siswa-siswi untuk mempelajari sejarah walisongo dalam bentuk game edukasi. Game edukasi ini dibuat menggunakan metode algoritme $A^{*}[5]$.

Penelitian yang dilakukan oleh Rena Lestari dengan judul Pengembangan Media Pembelajaran Pembelahan Sel dengan menggunakan Macromedia Flash untuk Kelas XII SMA menggunakan perpaduan antara metode Borg \& Gall dan Dick \& Carey. Penelitian ini didasarkan pada kuesioner bahwa pembelajaran Biologi untuk materi pembelahan sel selama ini masih dianggap sebagai suatu pembelajaran yang sulit karena materinya sulit dipahami, seperti proses pembelahan sel yang memang sulit untuk bisa dihadirkan secara nyata pada siswa. Meteri pembelahan sel berupa mitosis dan meiosis jika mengandalkan dari penyampaian materi oleh guru dirasa sangat kurang untuk memenuhi tingkat pemahaman siswa. Berdasarkan hasil analisis kebutuhan menunjukkan bahwa pengembangan media pembelajaran Biologi dengan menggunakan macromedia flash pada materi pembelahan sel 
dibutuhkan oleh guru dan siswa dalam proses Adventure Of Cali-Cali” bagi siswa SMA kelas XII pembelajaran [6].

jurusan MIPA. Kuesioner dibuat dalam pertanyaan dan jawabannya ditentukan dengan bentuk skala likert.

Berdasarkan pola yang dimiliki oleh game edukasi, pemain dituntut untuk belajar sehingga dapat Skala likert menggunakan beberapa butir pertanyaan menyelesaikan permasalahan yang ada. Pada penelitian ini Game edukasi tentang materi genetika akan membimbing pemain secara aktif untuk menggali informasi sehingga dapat memperkaya pengetahuan dan strategi saat bermain. Sehingga dapat meningkatkan tingkat pemahaman siswa.

\section{Metode Penelitian}

untuk mengukur perilaku individu dengan merespon 5 titik pilihan pada setiap butir pertanyaan, sangat setuju, setuju, tidak memutuskan, tidak setuju, dan sangat tidak setuju [8]. Butir-butir pertanyaan yang terdapat pada skala likert dikombinasikan sehingga membentuk sebuah nilai/skor.

Dalam pengolahan hasil pretest dan posttest menggunakan uji T-test dependent karena T-test Penelitian aplikasi game edukasi dibuat dengan dependent atau sering diistilahkan dengan Paired menggunakan metode waterfall. Metode ini termasuk Sampel t-Test, adalah jenis uji statistika yang bertujuan model sekuensial, sehingga penyelesaian satu set untuk membandingkan rata-rata dua grup yang saling kegiatan menyebabkan dimulainya aktivitas berikutnya. berpasangan. Sampel berpasangan dapat diartikan Penggunaan metode waterfall dianggap mempunyai sebagai sebuah sampel dengan subjek yang sama kemudahan untuk dimengerti, mudah digunakan, namun mengalami 2 perlakuan atau pengukuran yang requirement dari sistem bersifat stabil, baik dalam berbeda, yaitu pengukuran sebelum dan sesudah manajemen kontrol, serta bekerja dengan baik ketika dilakukan sebuah treatment [9].

kualitas lebih diutamakan dibandingkan dengan biaya dan jadwal [7]. Adapun tahapan-tahapan dalam pembuatan game edukasi dengan menggunakan Permainan terdiri dari kumpulan aturan yang pemodelan waterfall ditunjukkan pada Gambar 1.

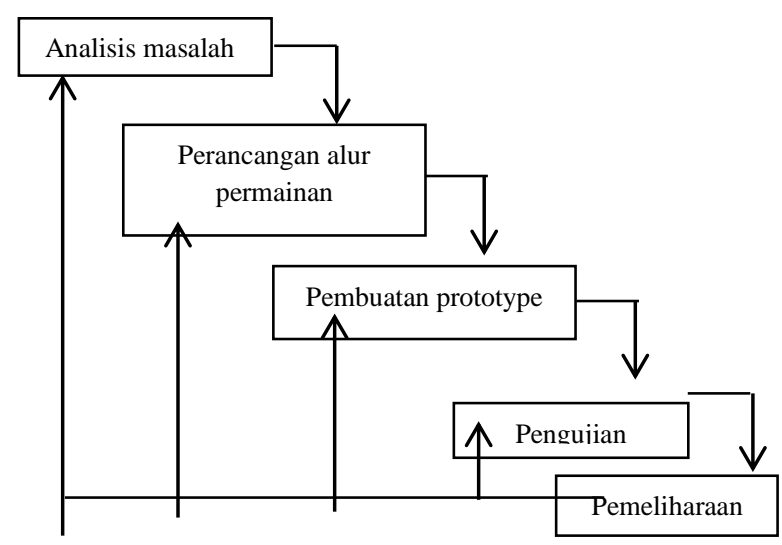

Gambar 1. Model Waterfall yang digunakan pada penelitian

\section{a. Analisis Masalah}

Dalam tahap ini dilakukan dengan observasi langsung dengan menyebarkan kuesioner mengenai tingkat pemahaman materi genetika menggunakan metode pembelajaran secara verbal dengan responden siswa SMA Negeri 1 Kroya kelas XII MIPA 1. Topik pertanyaan meliputi media yang digunakan sebagai media pembelajaran, paham atau tidaknya siswa dalam menguasai materi jika menggunakan metode pembelajaran secara verbal.

\section{b. Perancangan Alur Permainan} membangun situasi dengan memilih strategi yang akan digunakan untuk memaksimalkan kemenangan. Kemungkinan tindakan setiap pemain ditentukan dalam peraturan-peraturan yang ada. Dalam perkembangannya, setiap game developer berlombalomba untuk memberikan gameplay terbaik di dalam game-nya dan berusaha memahami kebutuhan konsumen [10].

Perancangan game menggunakan empat elemen dasar yang membentuk sebuah game [11], yaitu:

a. Mekanisme, adalah sekumpulan prosedur atau aturan-aturan yang dimiliki oleh sebuah game.

b. Alur cerita, adalah penggambaran kejadian-kejadian yang ada pada game tersebut.

c. Estetika, yang terdiri dari ide, strategi, dan semangat yang menjadikan game tersebut berbeda dari game lainnya.

d. Teknologi, teknologi yang digunakan dalam setiap game membuat game tersebut mampu melakukan hal-hal tertentu.

Pada perancangan game edukasi yang akan dibuat ditentukan melalui gameplay. Game ini ber-genre petualangan dengan karakter utama berupa gadis lucu bernama "CALI-CALI" yang melakukan petualangan berupa keingintahuan mengenai materi genetika. Di dalam perjalanan si Cali-cali dalam berpetualang, disuguhkan bermacam-macam rintangan berupa Kuesioner ini dibuat dua jenis dan dibagikan dalam 2 pertanyaan yang harus dijawab berdasarkan petunjuk periode waktu yang berbeda, yaitu sebelum dibuat dan penjelasan materi pada tiap levelnya. Di setiap game untuk mengetahui pendapat siswa tentang materi levelnya kemenangan akan ditandai dengan hasil genetika dan diberikan setelah game jadi untuk jawaban benar dan perolehan skor. Target pemain mengukur sejauh mana kemudahan dan manfaat yang dalam game ini adalah siswa SMA kelas XII, karena diperoleh dari penggunaan game edukasi "The berdasarkan kuesioner siswa kelas XII SMA N 1 Kroya 
menginginkan adanya game edukasi untuk d. Pengujian memudahkan dalam memahami materi genetika. Game petualangan ini dikemas dalam bentuk aplikasi yang berjalan di PC dan dapat digunakan sebagai media pembelajaran baru yang lebih menarik untuk guru maupun siswa.

\section{d. Pembuatan prototype}

Tahap pembuatan prototype ini dilakukan sesuai dengan rancangan alur permainan yang telah dibuat. Alur permainan dijadikan acuan dalam pembuatan scenario game yang dibangun. Pembuatan game menggunakan adobe flash CS6.

Skenario pada game edukasi yang dibangun terdiri dari 10 level. Pada gameplay level 1 pemain harus menjalankan karakter utama game yaitu Cali-Cali untuk berjalan melalui lintasan tanpa menyentuh batas lintasan, seperti pada Gambar 2. Jika pemain menyentuh batas lintasan maka akan game over, pemain bisa memilih untuk mengulang permainan atau kembali ke menu utama. Pada level selanjutnya gameplay akan sedikit lebih sulit dengan lintasan yang berkelok-kelok. Jalankan Cali-Cali hingga mencapai checkpoint untuk mendapatkan petunjuk berupa penjelasan tentang materi genetika pemain sudah mencapai checkpoint. Pemain akan diberi penjelasan singkat tentang materi genetika. Jika sudah mengerti, pemain akan melanjutkan permainan sampai finish.. Setelah pemain mencapai finish, pemain akan disuguhkan pertanyaan mengenai materi genetika berdasarkan penjelasan yang sudah dilihat pada checkpoint sebelumnya.

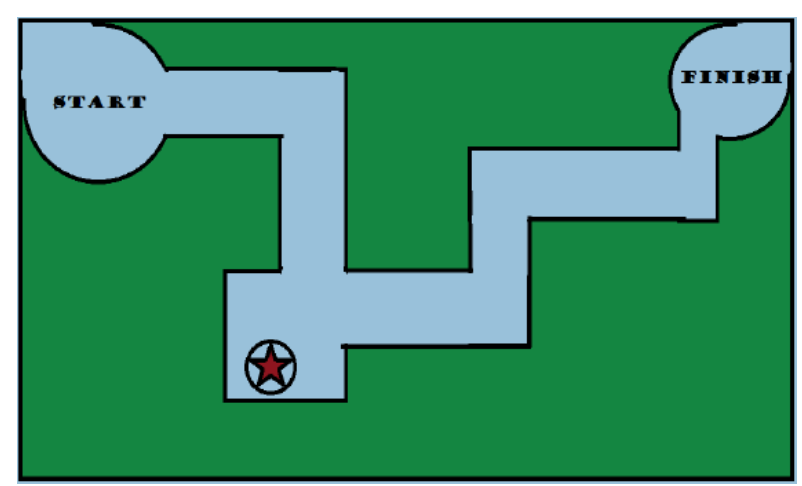

Gambar 2. Mock-up gameplay pada level 1

Tahap pengujian berupa pengujian fungsionalitas sistem yang dibangun. Sistem diujikan kepada siswa sebagai media belajar materi genetika.

\section{e. Pemeliharaan}

Pada tahap ini sistem di-instal dan dijalankan. Selain itu dilakukan juga pengecekan apakah aplikasi terjadi error atau tidak.

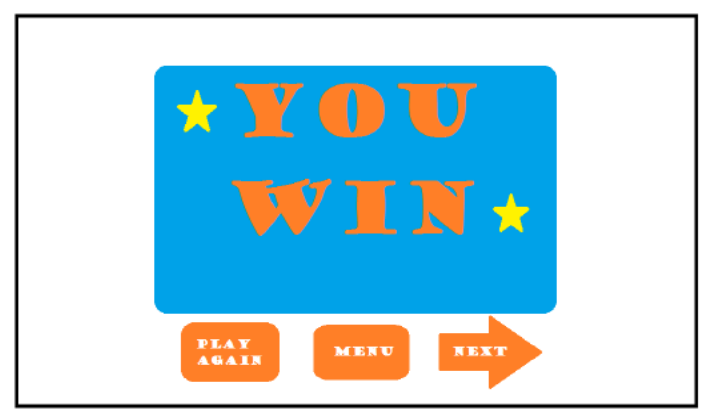

Gambar 3. Mock-up tampilan ketika berhasil menjawab kuis

\section{Hasil dan Pembahasan}

\subsection{Pengolahan Data Kuesioner}

Dari hasil kuesioner yang dilakukan dengan perlakuan sebelum diberi game, siswa merasa masih mengalami kesulitan dalam memahami materi genetika berdasarkan apa yang telah disampaikan oleh guru dan penjelasan yang ada di buku. Kebanyakan siswa membutuhkan media pembelajaran interaktif untuk memudahkan pemahaman siswa terhadap suatu materi khususnya materi genetika. Salah satu media interaktif yang dapat diaplikasikan dalam materi genetika adalah game edukasi. Dengan adanya game edukasi, siswa mampu belajar sambil bermain sehingga pembelajaran akan terasa menyenangkan dan mudah dipahami. Dari keseluruhan penjelasan di atas, siswa sangat mendukung terciptanya game edukasi untuk materi genetika yang diharapkan mampu menambah prestasi belajar siswa.

\subsection{Desain Antarmuka}

a. Tampilan Awal

Antarmuka Menu Game ini ditampilkan ketika aplikasi terbuka, terdapat tiga tombol dalam tampilan ini yaitu Ketika pemain telah berhasil menjawab pertanyaan, tombol play untuk memulai, tombol close untuk pemain dapat memilih untuk melanjutkan ke level menutup aplikasi dan juga tombol bantuan untuk selanjutnya atau mengulang lagi permainan atau bisa membuka tampilan bantuan seperti ditunjukkan pada juga kembali ke menu utama (Gambar 3). Proses Gambar 4.

tersebut berulang sampai dengan level 10 untuk dapat menyelesaikan seluruh game.

\section{b. Tampilan menu bantuan}

Tampilan ini muncul setelah memilih tombol bantuan yang berisikan aturan cara bermain game dan petunjuk memainkan game seperti ditunjukkan pada Gambar 5. 


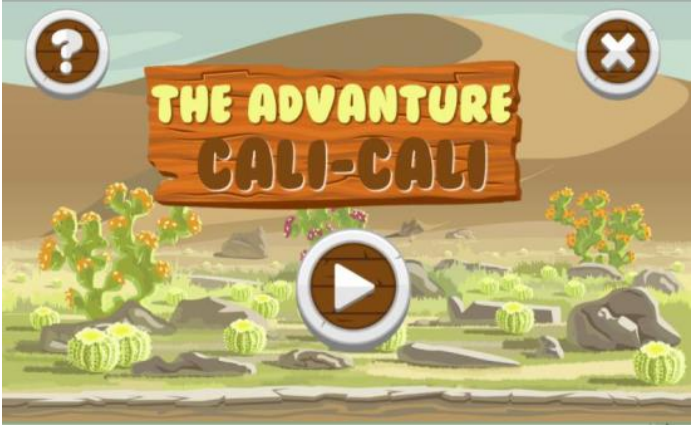

Gambar 4. Tampilan awal menu game

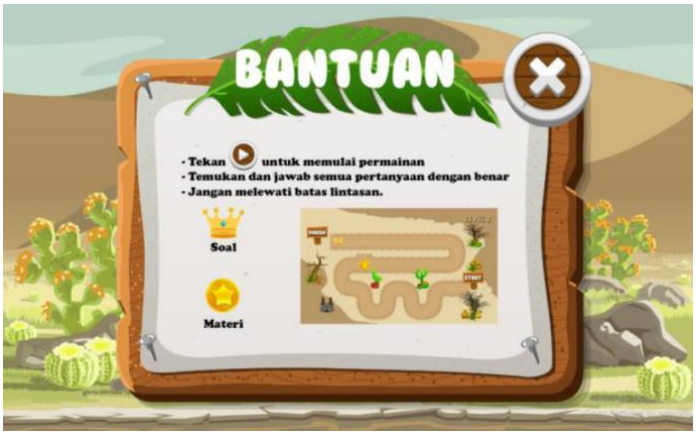

Gambar 5. Tampilan menu bantuan

\section{c. Tampilan in-game}

Tampilan ini muncul setelah memilih pilihan tombol play pada menu game. Pada tampilan ini pemain akan mengarahkan karakter sampai ke finish tanpa harus menyentuh tepi lintasan. Terdapat checkpoint di tengah lintasan sebelum menyentuh finish yang berisi clue di setiap level yang digunakan untuk menjawab soal setelah mencapai finish seperti ditunjukkan pada Gambar 6.

\section{d. Tampilan Clue}

Tampilan ini menunjukan clue atau petunjuk pada game tersebut yang nantinya dapat digunakan untuk menjawab soal ketika sudah mencapai finish. Petunjuk tersebut berupa ringkasan materi yang berhubungan dengan soal yang ada ketika mencapai finish seperti ditunjukkan pada Gambar 7.

\section{e. Tampilan Finish}

Tampilan ini menampilkan sebuah soal yang harus dijawab, seperti ditunjukkan pada Gambar 8. Soal berupa pilihan dengan dua opsi jawaban yaitu jawaban A dan jawaban B. Pemain harus memilih salah satu jawaban yang benar sesuai dengan clue yang sudah dilihat sebelumnya. Jika sudah menjawab maka akan muncul pernyataan benar atau salah. Jika jawaban benar maka akan memperoleh score atau nilai 10 , namun jika jawaban salah maka memperoleh score atau nilai 0. Jawaban benar ataupun jawaban salah tidak mempengaruhi berlangsungnya permainan. Siswa dapat melanjutkan permainan walaupun menjawab soal dengan salah, hanya saja siswa tidak mendapat skor jika menjawab dengan jawaban yang salah seperti ditunjukkan pada Gambar 9, dan jika benar seperti ditunjukkan pada Gambar 10.

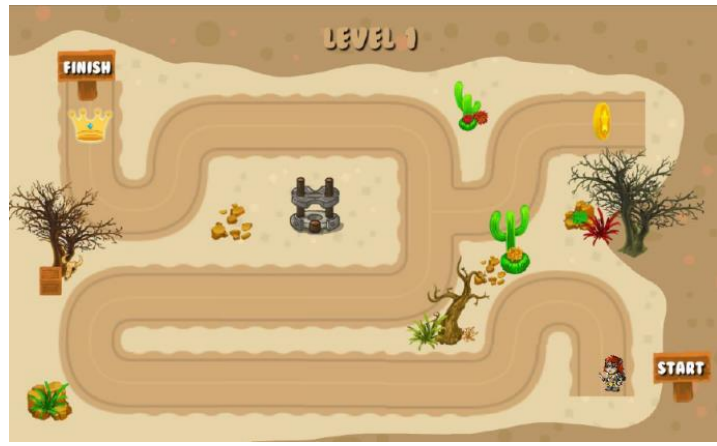

Gambar 6. Tampilan in-game

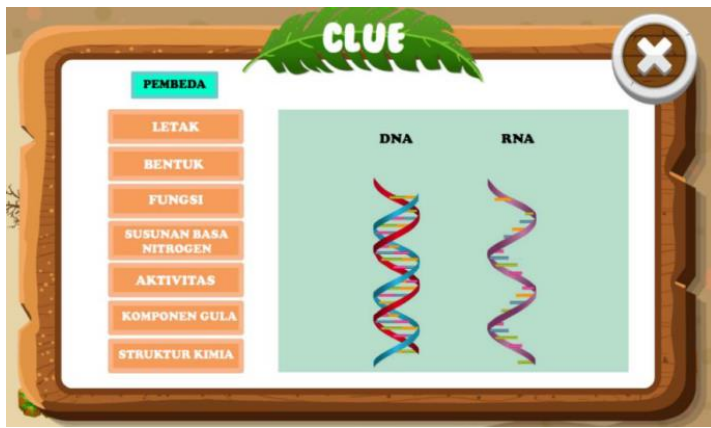

Gambar 7. Tampilan clue permainan

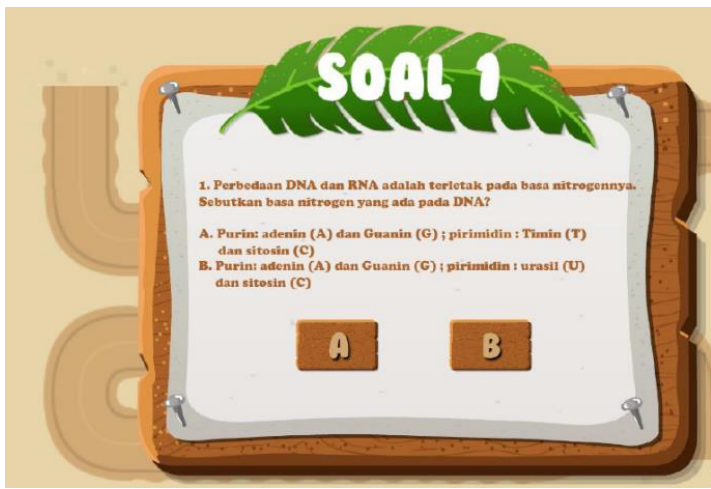

Gambar 8. Tampilan ketika mencapai finish berisi soal

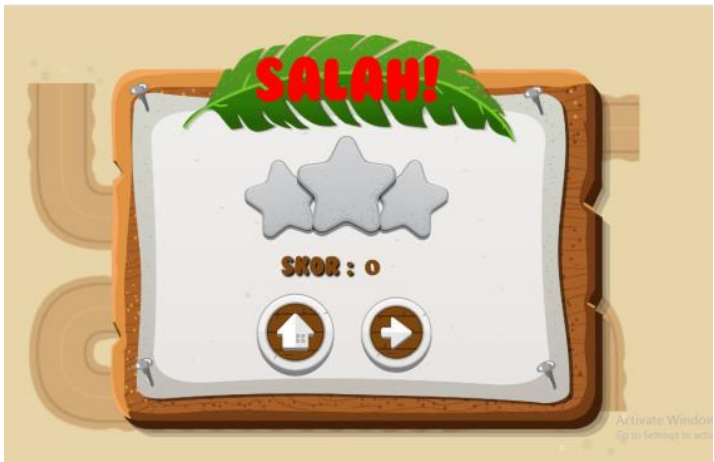

Gambar 9. Tampilan ketika jawaban salah

Jurnal RESTI (Rekayasa Sistem dan Teknologi Informasi) Vol . 3 No. 3 (2019) 349 - 356 


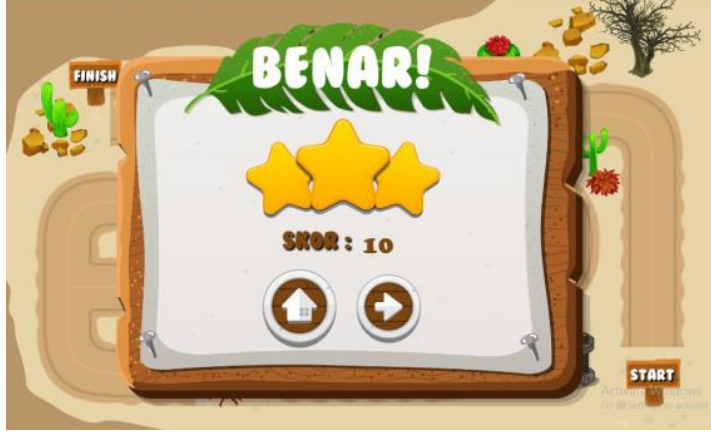

Gambar 10. Tampilan ketika jawaban benar

\section{f. Tampilan hasil akhir}

Tampilan ini menunjukan hasil akhir setelah menjawab semua soal yang ada pada game. Tampilan ini juga memperlihatkan berapa saja nomor yang benar maupun nomor yang salah. Pada tampilan ini juga menampilkan skor akhir dari kuis tersebut dan juga jumlah jawaban salah dan benar seperti ditunjukkan pada Gambar 11 .

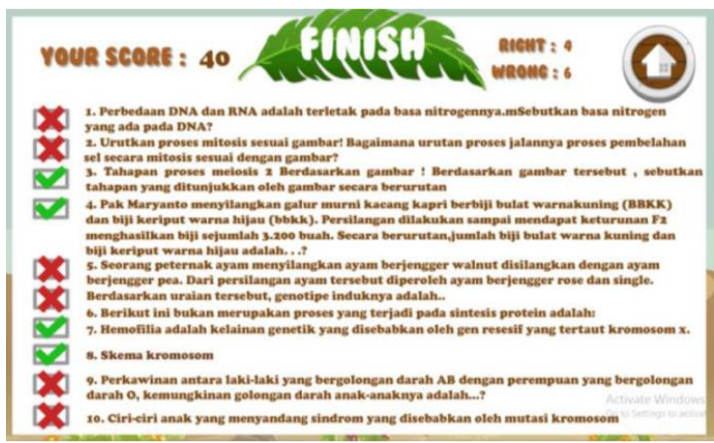

Gambar 11. Tampilan hasil akhir yang menunjukan skor

\subsection{Hasil Pretest}

Soal Pretest diberikan secara tertulis sebelum diberikan game. Soal pretest berisi 10 soal materi bab genetika dan siswa diberikan kebebasan untuk membuka buku ataupun catatan di dalam mengerjakannya. Hal ini tidak akan berpengaruh nantinya terhadap nilai yang dihasilkan oleh siswa, karena soal yang diujikan membutuhkan pemahaman dari suatu materi bukan hanya asal menjawab sesuai materi yang ada di buku. Pemberian soal pretest bertujuan untuk mengetahui sejauh mana tingkat pemahaman siswa terhadap materi genetika yang diajarkan oleh guru. Siswa yang mengikuti pretest berjumlah 31 siswa yang merupakan siswa kelas XII MIPA 1 SMA N 1 Kroya.

Dari hasil perolehan nilai pretest masih banyak siswa yang belum memenuhi standar Kriteria Ketuntasan Minimal (KKM). Standar KKM untuk mata pelajaran biologi materi genetika adalah 68. Dari hasil perolehan nilai pretest pada 31 siswa kelas XII MIPA 1 SMA N 1 Kroya dapat diperoleh persentase perbandingan siswa yang sudah memenuhi KKM dan siswa yang belum memenuhi KKM seperti ditunjukkan pada Gambar 12.

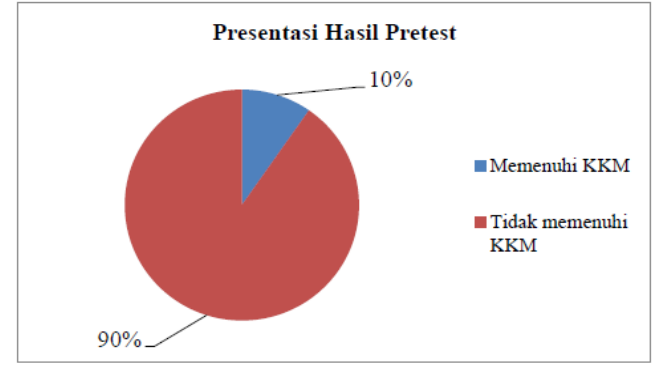

Gambar 12. Gambar persentase hasil pretest

Berdasarkan Gambar 12 didapatkan hasil bahwa persentase siswa yag sudah memenuhi KKM adalah 9,7\% dan siswa yang belum memenuhi KKM adalah $90,3 \%$. Dari hasil persentase tersebut diketahui bahwa dari ke 31 siswa hanya 1 siswa yang nilainya lulus sesuai Kriteria Ketuntasan Minimal (KKM), sedangkan 30 lainnya masih dibawah standar Kriteria Ketuntasan Minimal (KKM). Berdasarkan nilai dan hasil persentase yang diperoleh tersebut, guru pengampu mata pelajaran biologi yaitu Ibu Kurnianingsih, S.Pd sangat mendukung penulis dalam pembuatan game edukasi yang bertujuan agar siswa lebih memahami materi genetika dan mampu meningkatkan nilai pada mata pelajaran biologi khususnya bab genetika.

\subsection{Hasil Posttest}

Soal posttest tercantum di dalam game yang nantinya akan dimainkan oleh siswa. Soal posttest berisi 10 soal materi bab genetika yang dimasukkan ke dalam tiap level permainan yang berbeda. Pemberian soal posttest bertujuan untuk mengetahui sejauh mana tingkat pemahaman siswa terhadap materi genetika yang diajarkan oleh guru dan materi yang tercantum di dalam game. Soal posttest yang diberikan kepada siswa adalah soal yang sama dengan soal pretest, hal ini bertujuan agar memudahkan di dalam pengukuran perubahan nilai antara perlakuan yang sebelum diberi game dengan perlakuan sesudah diberi game. Kemasan antara kedua jenis soal ini berbeda, hal itulah yang membuat siswa tidak menyadari bahwa soal itu adalah sama. Siswa yang mengikuti posttest berjumlah 31 siswa yang merupakan siswa kelas XII MIPA 1 SMA N 1 Kroya. Soal posttest yang diberikan kepada siswa yang dikemas dalam tiap level permainan berbeda dapat dilihat pada lampiran 8.

Dari kesepuluh soal tersebut siswa diminta mengerjakan tiap levelnya yang sudah diberikan materi yang berkaitan dengan soal tersebut pada tiap level. Materi yang terdapat berupa video dan ringkasan materi. Materi yang disediakan tiap level berbeda-beda tergantung dengan soal yang nantinya akan diberikan. Materi dan soal yang diberikan sudah mencakup semua subbab yang ada pada bab materi genetika. Sehingga dapat digunakan sebagai acuan tingkat pemahaman materi genetika. Hasil yang diperoleh berdasarkan nilai 
posttest dikategorikan mengalami peningkatan terhadap nilai pretest seperti ditunjukkan pada Gambar 13.

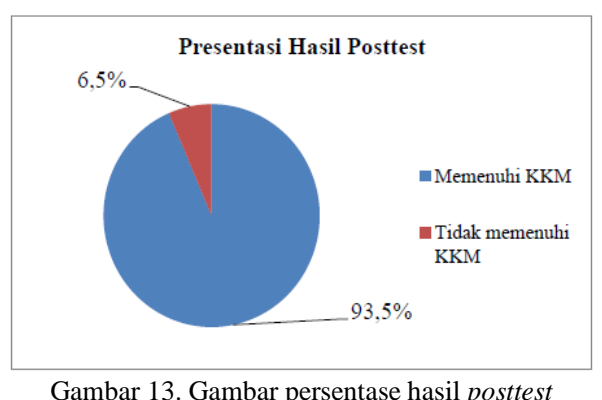

Gambar 13. Gambar persentase hasil posttest

Berdasarkan Gambar 13 didapatkan hasil bahwa persentase siswa yag sudah memenuhi KKM adalah 93,5\% dan siswa yang belum memenuhi KKM adalah $6,5 \%$. Walaupun belum semua siswa mampu lulus sesuai standar batas KKM, namun hasil yang diperoleh dengan media pembelajaran game edukasi mampu membuat siswa lebih memahami materi genetika yang dibuktikan dari peningkatan nilai pretest ke posttest. Perbandingan persentase antara hasil pretest dan posttest bagi siswa yang belum memenuhi standar KKM seperti ditunjukkan pada Gambar 14.

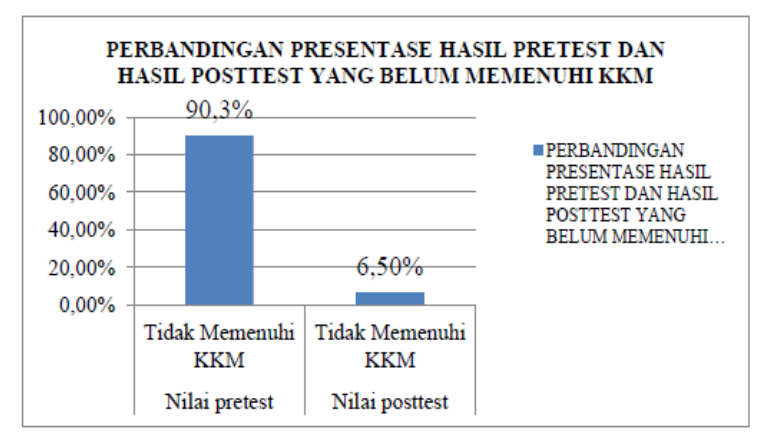

Gambar 14. Gambar perbandingan persentase antara hasil pretest dan posttest bagi siswa yang belum memenuhi standar KKM

Berdasarkan Gambar 14 didapatkan penurunan jumlah siswa yang belum memenuhi standar KKM yaitu dari persentase tidak lulus sebesar 90,3\% yang didapatkan pada hasil pretest menjadi 6,50\% pada hasil posttest.

Penurunan tersebut menunjukkan bahwa dengan adanya game edukasi genetika mampu meningkatkan nilai siswa sehingga mampu mencapai standar KKM. Nilai yang meningkat bisa dipertahankan dengan menggunakan game edukasi secara bertahap, tidak hanya pada materi genetika saja, nantinya semua materi dapat dibuat dengan menggunakan game edukasi.

\subsection{Pengujian Hasil Pretest dan Posttest}

Hasil nilai pretest dan posttest diolah dan diuji secara statistik dengan aplikasi SPSS dan menggunakan uji t sampel berpasangan saling berhubungan (Dependent $\mathrm{t}$ test). Penggunaan uji t dependent atau paired sample $\mathrm{t}$ test karena uji $\mathrm{t}$ dependent digunakan untuk membandingkan rata-rata dua grup yang saling berpasangan. Sampel berpasangan dapat diartikan sebagai sebuah sampel dengan subjek yang sama namun mengalami 2 perlakuan atau pengukuran yang berbeda, yaitu pengukuran sebelum dan sesudah dilakukan sebuah treatment. Treatment dalam hal ini adalah perlakuan sebelum diberikan game dan perlakuan sesudah diberikan game. Penggunaan uji t dilakukan untuk mengetahui dan menguji efektifitas suatu perlakuan terhadap suatu besaran variabel yang ingin ditentukan, misalnya untuk mengetahui efektifitas metode penyuluhan terhadap peningkatan pengetahuan dari responden.

Dalam penelitian ini uji t digunakan untuk mengetahui efektifitas perlakuan diberikan game terhadap peningkatan pemahaman siswa yang dibuktikan dengan peningkatan prestasi belajar. Hasil dari Uji T berfungsi untuk mengetahui perbedaan nilai rata-rata antara dua kelompok atau data, yaitu antara pretest dan posttest. Setelah dua data di-input dan diolah secara benar dengan menggunakan program SPSS akan dihasilkan suatu output dari data pretest dan posttest tersebut yang menunjukkan perbedaan nilai rata-rata antara perlakuan pretest (sebelum diberi game) dan perlakuan posttest (sesudah diberikan game).

\section{Kesimpulan}

Hasil penelitian yang telah dilakukan dapat ditarik kesimpulan bahwa game edukasi materi Genetika dapat digunakan sebagai media pembelajaran alternatif yang dapat memberikan siswa pengalaman belajar baru yang menyenangkan. Game edukasi materi genetika dapat meningkatkan pemahaman siswa terhadap materi genetika yang ditunjukkan oleh peningkatan nilai (ada perbedaan yang signifikan) antara nilai/skor rata-rata pretest dan postest ( $\mathrm{N}$ pretest $\neq \mathrm{N}$ posttest) dengan nilai kenaikan sebesar $83,8 \%$, yang diperoleh dari persentase nilai siswa yang tidak memenuhi KKM pada pretest dikurangi dengan persentase nilai siswa yang tidak memenuhi KKM pada posttest.

Perlu adanya variasi jenis soal yang beragam pada game edukasi materi genetika "The Adventure Of CaliCali" dengan cara menambah jumlah banyaknya soal agar dapat menambah wawasan siswa untuk mengetahui jenis-jenis soal yang ada pada materi genetika tersebut dan dapat dijadikan sebagai uji latihan soal siswa.

\section{Ucapan Terimakasih}

Siswa kelas XII MIPA 1 SMA N 1 Kroya yang telah membantu dalam proses pengambilan data.

\section{Daftar Rujukan}

[1] Shaw, K.R.M., et al. "Essay Contest Reveals Misconceptions of High School Students in Genetics Content". Genetics. 2008 March; 178(3): 1157-1168. 2008.

[2] Venville \& Treagust. "Teaching about the gene in the Genetic Information Age". Australian Science Teachers Journal. 2002. 
[3] Handriyantini, Eva, S.Kom, M.MT. , "Permainan Edukatif [7] (Educational Games) Berbasis Komputer untuk Siswa Sekolah Dasar". Malang : Sekolah Tinggi Informasi \& Komputer Indonesia, 2009.

[4] Purnomo, F.A, Eko.H.P, Taufiqurrahman .N.P, Firma.S, \& Inda.P.L, "Pembuatan Game Edukasi Petualangan Si Gemul Sebagai Pembelajaran Pengenalan Daerah Solo Raya pada Anak", Jurnal Simetris UNS. Vol 7 No 2, 2016.

[5] Widiastuti, N.I, \& Setiawan I. , "Membangun Game Edukasi Sejarah Walisongo", Jurnal Ilmiah Komputer dan Informatika (KOMPUTA) FTIK Unikom. Vol 1 No 2, 2012.

[6] Eltariza, N, "Model Pembelajaran dengan Media Pembelajaran Berbasis Blog Untuk Meningkatkan Hasil Belajar Menggambar Animasi Siswa pada Mata Pelajaran Dasar Macromedia Flash 8". Jurnal Teknologi Pendidikan, (online), 10(2):80-85, 2011.
Dewi,G.P.F, "Pengembangan Game Edukasi Pengenalan Nama Hewan dalam Bahasa Inggris Berbasis Macromedia Flash", Yogyakarta: UNY, 2012.

[8] Fahrurrozi,Imam, \& Azhari S.N, "Proses Pemodelan Software Dengan Metode Waterfall dan extreme Programming", Yogyakarta: Artikel Program Studi Ilmu Komputer,Universitas Gadjah Mada, 2012.

[9] Sugiyono. 2010. "Metode Penelitian Kuanttatif Kualitatif dan RND”. Bandung: Alfabeta. 2010.

[10] Ansor, M.Y , "Pengembangan Media Pembelajaran Bergenre Role Playing Game Pada Instalasi Perangkat Jaringan LAN Di SMK", Bandung : Universitas Pendidikan Indonesia, 2015.

11] Chowanda, Andry. "Perancangan Game Kartu Interaktif Berbasis Android Menggunakan Augmented Reality", Jurnal Comtech Binus University, Vol 2 No 2. 2011 